\title{
Jogo de corpo, corpo do jogo: futebol e masculinidade
}

\author{
ELIENE LOPES FARIA
}

\begin{abstract}
resumo $\mathrm{O}$ objeto deste texto são as práticas de futebol como contextos de aprendizagem da identidade de gênero. Elaborado a partir de uma incursão etnográfica no cotidiano de futebol dos jovens de um bairro de Belo Horizonte, o trabalho dá visibilidade a importantes aspectos (do processo de aprendizagem) que envolvem a constituição da masculinidade e as relaçóes de gênero em jogo nesse esporte. Revela, portanto, que a aprendizagem do futebol está difusa nos diferentes modos de participação na prática social e envolve mais do que técnicas, táticas e regras. Nas práticas futebolísticas cotidianas os jovens praticantes aprendem o futebol e nele constituem também identidades. Não se trata, entretanto, de um processo de assimilação passiva, em que o corpo vai sendo moldado. Ao contrário, numa relação tensa e sutil, a cultura futebolística marca o corpo dos praticantes ao mesmo tempo em que é marcada por ele.
\end{abstract}

palavras-chave Futebol. Aprendizagem. Gênero. Identidade. Masculinidade

\section{Introdução}

A masculinidade, como a feminilidade, é um saber ver, um perceber uma parte do mundo que ao outro escapa (La Cecla, 2005, p. 7).

O presente trabalho se constitui como parte das reflexóes contidas em minha tese de doutorado (intitulada $A$ aprendizagem da e na prática social: um estudo etnográfico sobre as práticas de aprendizagem do futebol em um bairro de Belo Horizonte) defendida na Faculdade de
Educação da Universidade Federal de Minas Gerais em 2008. Interessada em compreender os modos de aprendizagem do futebol (esporte popular no Brasil), mergulhei no cotidiano das práticas futebolísticas ${ }^{1}$. Este esporte foi tomado, portanto, como prática cultural em que os processos de aprendizagem são indivisíveis da produção cotidiana. Assim, utilizei operadores teóricos - sobretudo a abordagem da aprendizagem situada de Lave e Wenger (1991) ${ }^{2}$ - que permitissem compreender as práticas futebolísticas dos jovens como contextos de constituição de habilidades e identidades ${ }^{3}$. Esse movimento possibilitou desvelar importantes aspectos da aprendizagem desse esporte, oferecendo pistas para a compreensão de como tais processos ocorrem.

Produzida a partir de um esforço etnográfico, a pesquisa foi realizada em um bairro de Belo Horizonte em 2005/2006 - contexto dotado de espaços diversificados para a aprendizagem do futebol (escola pública, "escolinhas" de esportes, projetos sociais, campos de várzea, praças esportivas, terrenos baldios, ruas, becos, etc.). ${ }^{4}$ Seguindo as orientaçóes propostas na teoria da aprendizagem situada de Lave e Wenger (1991), escolhi um contexto social em que os recursos para a aprendizagem do futebol vinham de várias fontes (não apenas da atividade pedagógica); em que era possível observar a ocorrência de intricada estrutura de aprendizagem do futebol; em que a prática criava um currículo potencial (de aprendizagem), no sentido amplo; enfim, em que o futebol fazia parte do dia-a-dia dos jovens. Focando nas prá- 
ticas futebolísticas juvenis, busquei dar relevo aos aspectos sutis e invisíveis que permitissem compreender seus modos de aprendizagem.

Situado na região nordeste de Belo Horizonte, às margens do Anel Rodoviário (BR-381), o bairro escolhido para a pesquisa é eminentemente residencial. Diferenças socioeconômicas, que revelam aspectos importantes dos modos de vida dos seus moradores, podem ser observadas na arquitetura local (casas grandes de quintais amplos, nas proximidades da avenida principal, e barracos de lona e/ou madeira, nas imediaçóes do Anel Rodoviário) e na distribuição espacial. Essas diferenças podem ser observadas também nas condiçóes materiais de vida dos moradores. Enquanto os que moram na parte central do bairro têm acesso a água, esgoto, luz e outros bens, muitos que ocupam o entorno do Anel Rodoviário e proximidades convivem com a precariedade, como desemprego, moradias insalubres (umidade, pouca luz e espaço), barulho, lixo, inundaçôes, chuva. Para estes, o cotidiano tem uma dimensão pública acentuada. Isso porque é na rua que crianças, mulheres e homens passam grande parte do tempo (para lavar roupas, para brincar, para beber cerveja, para namorar, para conversar, para escapar do calor, para olhar o movimento dos que ali fazem ponto de passagem). O cotidiano do bairro é, contudo, dinâmico; e se os lugares são fixos, as pessoas não. Jovens, crianças e adultos deste bairro e dos vizinhos se misturam no cotidiano na escola $^{5}$, na Praça de Esportes, no campo de futebol, no mercadinho, no bar, na rua - sobretudo nas práticas de futebol.

O princípio que fundamentou o trabalho é que se aprende sempre, nas diferentes situaçóes. Nas práticas futebolísticas, portanto, os jovens estão sempre aprendendo alguma coisa. Para abordar o tema, contudo, foi preciso superar a ideia de aprendizagem de gestos (descontextualizados, sem significados e sem história) ${ }^{6}$. Parti do princípio de que as práticas esportivas não são aprendidas apenas como gestos moto- res, pois considero que os esportes são práticas culturais e, desse modo, cheios de significados. É preciso salientar, entretanto, que a complexidade da prática futebolística mostrou que aprender (a cultura) não se esgota na consideração de gestos motores e significados, mas que, no processo de incorporação da prática social, outros aspectos estão em jogo. Assim, a pesquisa buscou dar relevância ao conjunto de elementos que envolvem a aprendizagem desse esporte - significados, disposiçóes corporais, tipos de atenção, emoçóes e conhecimentos que caracterizam a prática. Operei, portanto, com o conceito ecológico de cultura (como habilidade) de Ingold $(2000,2001)^{7}$. Ao lado do conceito de participação (Lave e Wenger, 1991), trouxe para o centro das análises a noção de habilidade (como campo total de relaçóes constituídas que no caso do futebol envolvem o jogador, a bola, o outro, o ambiente) e tentei descrever esse campo de relaçóes.

O texto etnográfico que segue é um recorte do referido trabalho e descreve as práticas futebolísticas cotidianas de um grupo de jovens dentro e fora da escola, dando relevo às aprendizagens constituídas nos diferentes contex$\operatorname{tos}^{8}$. Aborda, desse modo, de forma pontual, as questôes que envolvem as relaçôes de gênero presentes no futebol dos jovens no bairro pesquisado (que permite compreender os homens como participantes legítimos da prática social) e a prática futebolística também como exercício de masculinidade nesse contexto.

\section{"Futebol é coisa de homem": os praticantes legítimos da prática social}

Tomando como referência as reflexóes de Lave e Wenger (1991), busquei compreender o universo de aprendizagem do futebol como constituído por praticantes que possuem legitimidade de participação. Segundo Lave e Wen- 
ger (1991, p.29), a aprendizagem se dá a partir da participação periférica legitimada (LPP) ${ }^{9}$ na prática social, ou seja, “os aprendizes participam inevitavelmente em comunidade de prática em que o domínio do conhecimento e das habilidades requer um mover-se para a participação plena” nas práticas socioculturais. É importante destacar, porém, que para o conceito de LPP a noção de legitimidade é central. Considerada uma abertura, um modo de ganhar acesso a fontes de entendimento, a legitimidade é uma condição sine qua non para a participação e, consequentemente, para o conhecimento. Enfim, a estrutura social da prática, "suas relaçôes de poder e suas condiçóes para a legitimidade definem possibilidades para a aprendizagem”.

Diariamente no bairro, o futebol era aprendido na prática. Procurando conhecer os contextos de produção do futebol no bairro, pude percebê-los, entretanto, como contextos generificados ${ }^{10}$. Isso porque as práticas futebolísticas que ocorriam cotidianamente no bairro eram marcadas por amplo engajamento dos jovens do sexo masculino e pela ausência (ou exclusão) das mulheres em muitos contextos. Mas essa não era uma singularidade do futebol produzido no bairro pesquisado. Vários estudos possibilitam compreender a generificação no esporte como parte de processos culturais mais amplos na sociedade (Altmann, 1998; Goellner, 2000; Pacheco; Cunha Junior, 1997; Sousa, 1994; I997).

No esporte, a generificação - expressa na distinção de modalidades femininas e masculinas e nas relaçóes que envolvem a prática - é constituinte. Segundo Sousa e Altmann (1999), com o advento do esporte moderno as mulheres mantiveram-se como perdedoras, uma vez que eram (e ainda são) compreendidas como frágeis em relação ao homem. Segundo as autoras, aos homens era permitida/incentivada a prática de esportes que exigiam maior vigor e esforço físico, o confronto corpo a corpo e movimentos violentos (futebol, por exem- plo). Para as mulheres eram indicadas práticas que preservassem a suavidade de movimentos e a distância de outros corpos, como a ginástica rítmica, o voleibol e a dança.

De fato. Do tempo em que as mulheres eram espectadoras da maioria dos esportes coletivos, proibidas de realizar algumas práticas (como o futebol), até os dias atuais, houve grande mudança. Hoje as mulheres são protagonistas de muitas modalidades esportivas. Contudo, ainda não se pode afirmar a igualdade de acesso/inserção de homens e mulheres em algumas modalidades esportivas (que permanecem generificadas).

Como afirmam Dornelles e Molina Neto (2003, p. 90), "as transformaçóes sociais e culturais ocorridas nas últimas décadas do século XX foram elemento essencial, porém ainda insuficiente, para a promoçáo da participaçáo esportiva feminina”. Assim, algumas modalidades, como é o caso do futebol, ainda apresentam, no "início do século XXI, uma gama de discriminaçóes e preconceitos quanto à ação das mulheres, seja em clubes, espaços populares ou na escola”. Não há como negar que, como outras atividades, a prática do futebol, no contexto histórico-cultural brasileiro, está registrada como prática masculina - o que não significa uma universalização desse significado $^{11}$. Isso faz com que em muitas situaçóes a participação de mulheres seja considerada um desvio (Guedes, 2006, p. 50).

Afirma Goellner (2000, p. 81):

Criado, modificado, praticado, comentado e dirigido por homens, o futebol parece pertencer ao gênero masculino, como parece também ser seu o domínio de julgamento de quem pode/deve praticá-lo ou não. É quase como se à mulher coubesse a necessidade de autorização masculina para tal. [...] Ou seja, é um jogo para machos.

A pesquisa de campo destacou a ampla participação masculina no universo do futebol. 
Conversando com o professor de Educação Física sobre os temas/conteúdos de ensino das aulas na escola, por exemplo, ele falou sobre o acentuado interesse masculino pelo futebol. Mas foi nas redações dos alunos (122 homens e 110 mulheres), feitas no primeiro dia de aula, que encontrei pistas sobre esse interesse.

Orientando os alunos das turmas da $5^{\mathrm{a}}$ à $8^{\mathrm{a}}$ séries do ensino fundamental para escreverem sobre as expectativas para as aulas de Educação Física, o professor propôs a redação de um texto que tivesse estes itens: A) o que eu espero da Educação Física; B) o que eu gosto de fazer; C) o que eu não gosto de fazer; D) deixe uma mensagem ou sugestão. As respostas que os alunos deram às questôes $\mathrm{B}$ e $\mathrm{C}$ permitem reflexôes importantes para compreender o futebol:
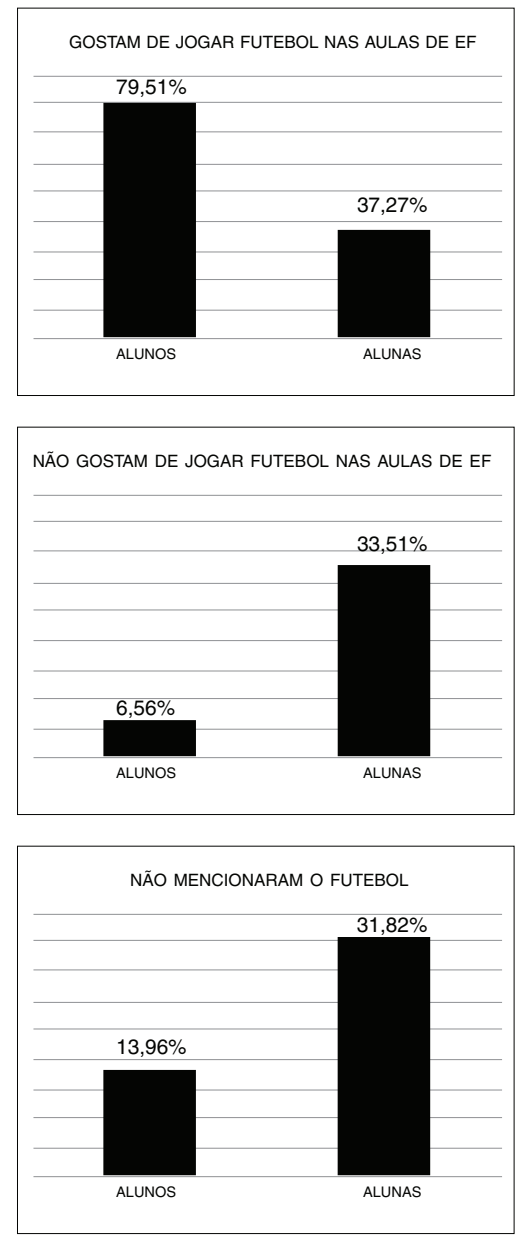

Fonte: Faria (2008).
Esses dados mostram que o futebol era prática presente nas expectativas, principalmente dos jovens do sexo masculino. Somado o número de mulheres que não gostavam do futebol com o número das que não o mencionaram como possibilidade de prática, chega-se a um número importante: o futebol não estava nas expectativas de prática das aulas de Educação Física para 69 delas (62,73\%). Para os homens, o resultado foi de 25 (20,49\%). Chamou a atenção também, na leitura desses dados, outro fator. Enquanto os jovens do sexo masculino mantinham regularidade no interesse por esse esporte nas séries do ensino fundamental, apenas as mulheres mais avançadas na escolarização demonstravam interesse no jogo. Em outras palavras: enquanto a queimada (jogo popular no Brasil) era foco de muito interesse para as alunas da $5^{\mathrm{a}}$ e da $6^{\mathrm{a}}$ séries (36 de um total de 47 alunas, ou seja, 76,59\%, citaram a queimada em resposta à questão B), para as alunas das turmas da $7^{\mathrm{a}}$ e da $8^{\mathrm{a}}$ séries houve um declínio do interesse no jogo (29 de um total de 63 alunas, o que equivale a 46,03\%). O maior interesse das alunas da $5^{\mathrm{a}}$ e da $6^{\mathrm{a}}$ séries pela queimada também foi observado no cotidiano da escola. Na Educação Física dessas turmas o jogo se repetia, aula após aula. Nas turmas da $7^{\mathrm{a}}$ e da $8^{\mathrm{a}}$ séries ele se tornava esporádico. Contudo, é preciso considerar que não havia homogeneidade na produção da queimada e do futebol entre as mulheres. Assim, era possível também observar uma ou outra turma da $6^{\mathrm{a}}$ série envolvida com o futebol e alunas que, na $7^{\text {a }}$ série, ainda preferiam jogar queimada.

Os dados citados revelam dois importantes aspectos. Primeiro: um crescente interesse feminino pelo futebol no decorrer da escolarização. Segundo: o futebol como parte do processo de "socialização primária" dos meninos (Guedes, 1998). Estes, ao contrário das meninas (que iniciavam a prática do futebol na escola), já chegavam à escola com mais inte- 
resse e em processo de aprendizagem do jogo. Sobre essa questão Regina ${ }^{12}$ ( $6^{\mathrm{a}}$ série) relatou o seguinte:

As meninas da sala, quase nenhuma gosta de jogar (futebol), aí quando o horário é da gente são só quatro meninas pra jogar futebol. [...] São mais meninos pra jogar futebol. Não sei, eles gostam mesmo. Meninas... pode olhar que tem poucas, pouquíssimas meninas que gostam de jogar futebol, não são muitas. Agora a maioria dos meninos gosta. [...] Ah, queimada, queimada é o que elas gostam mais.

A pequena participação das mulheres no futebol do recreio e no festival de jogos da escola e a separaçáo de meninos e meninas para a realização das práticas futebolísticas nas aulas de Educação Física eram também reveladoras da generificação. Jogando futebol "somente" nas aulas de Educação Física, a maioria das jovens do bairro estava distante de conhecer o seu universo de significação, emoção e identificação. $\mathrm{Na}$ leitura das redaçóes dos alunos encontrei expressáo para questóes em jogo nas práticas futebolísticas:

Para os homens sempre o normal, ou seja, o futebol (Bruno, $8^{\mathrm{a}}$ série).

\section{[...] Eu não gosto de fazer Educação Física e} nem jogar futebol é coisa de meninos (Janaina, $8^{a}$ série).

[...] eu pelo menos, gosto de jogar futebol, jogar baralho... e o que eu não gosto de fazer é jogar queimada [...] eu quero que a gente faça muita atividade de macho (Clayton, 6a série).

\section{[...] peteca é para meninas (Maurício, 5 $5^{\mathrm{a}}$ série).}

[...] eu quero que o professor dê mais futebol que os outros esportes, porque é melhor futebol que os outros esportes (Hugo, $5^{\mathrm{a}}$ série).
Raramente as alunas da escola participavam dos jogos de futebol com os alunos. Mas, mesmo quando a participação era possível, isso não significava que era fácil elas passarem a fazer parte. Ao contrário, qualquer motivo era suficiente para a exclusão das mulheres do futebol. A descrição que segue (de uma turma da $8^{a}$ série) permite melhor compreender o significado do futebol no universo feminino. Era como se às alunas já fosse o bastante penetrar no espaço sagrado do futebol (a quadra da escola), durante o recreio, uma vez por semana.

Os meninos pegam as bolas disponíveis no espaço e começam a chutar (2 meninas também). Depois de um tempo iniciam a organização dos times e convidam as meninas a participar, visto que o número de jogadores está insuficiente. Quatro meninas logo aceitam o convite e seguem para o centro da quadra, onde ocorre a divisão dos times. Já estão para iniciar o jogo quando o professor chega à quadra com alguns alunos da turma de Cláudia (a outra professora de Educaçáo Física da escola) que estavam na pracinha e já haviam jogado no horário anterior (essa turma tinha aulas de Educação Física geminadas). Os meninos dizem que agora não precisam mais das meninas, pois eles jogariam com os meninos do $1^{\circ}$ ano. As meninas resistem um pouco a sair da quadra. Dizem para o professor que é a vez delas de começar a aula jogando. O professor diz a elas então: "Hoje vocês jogaram no recreio". Algumas das meninas afirmam não ter participado no referido jogo de futebol, mas saem do espaço da quadra.

Segundo Damo (2005, p. 139), os meninos jogam futebol "para se fazerem meninos", ou seja, "o futebol no Brasil é marcado por um arbitrário cultural que o define como um espaço privilegiado da homossociabilidade masculina; de certo modelo de masculinidade". Desse modo, as mulheres, de uma forma geral, "ten- 
dem a excluírem-se do futebol na medida em que ele é culturalmente marcado como um jogo para meninos. Quando isso não acontece, elas são então excluídas". Os argumentos mais frequentes são de que "elas não sabem jogar" e por isso "atrapalham o jogo" (Damo, 2005, p. 157):

Ah, eu acho que tem algumas meninas que têm uma certa facilidade pra jogar futebol, mas acho que a maioria das meninas não gosta de jogar futebol por causa que expóe muito a beleza delas, usar calção, esse negócios, isso é mais coisa masculina do que pra feminino, por isso que elas não seguem muito jogando futebol (Schiva, jovem de 17 anos) (grifos meus).

Eu acho que a mulher, não tem inteligência, ela não tem a coordenação pra jogar futebol que o homem tem. [...] Mesmo em seleção brasileira, por mais craque que ela seja de domínio, [...] mas na hora de jogar coletivo, as mulheres ainda não têm essa coordenação que o homem tem coletiva. (professor de Educação Física) (grifos meus)

Nós tivemos um time de meninas lá, só que elas foram muito mais desanimadas que os meninos, [...] rapidinho também desfizeram. Ficou uma ou outra querendo jogar no meio dos meninos, só que não dava muito certo. Os meninos assim, por mais que, igual tinha uma menina lá que tinha bastante habilidade, mas comparando com homem, homem tem mais corpo, tem mais força que ela então não dava pra gente colocá-los juntos (Mário, auxiliar do Projeto Social) (grifos meus).

A naturalização do futebol como prática masculina ganhou destaque também no decorrer do festival de jogos na Semana do Estudante. $\mathrm{O}$ jogo entre professores e alunos (marcado como um clássico Cruzeiro e Atlético) tinha apenas homens. Como, na escola, não havia o número de professores do sexo masculino suficiente para formar um time, participaram do time dos professores/Cruzeiro três pedreiros que prestavam serviços na escola naquele momento. Outro professor assumiu a posição de juiz do jogo. Nenhum estranhamento para isso! Nenhuma reivindicação de participação feminina. Parece que apenas eu me "incomodei" com tal fato.

A entrada de uma aluna no time dos alunos/Atlético, contudo, me fez perceber o que estava em jogo na exclusão das mulheres. Essa jovem, que participava do grêmio estudantil, como os demais jogadores do time dos alunos, e que também possuía desenvoltura nos jogos de futebol das aulas de Educação Física, entrou em campo ao final do segundo tempo de jogo. Mas quando o jogo já estava praticamente definido (6 X 0 para os alunos/Atlético). Posicionada perto do gol, a jovem participava do jogo principalmente recebendo passes dos colegas para finalizar com chutes a gol. Em dado momento, num chute certeiro, a jovem "vazou" o goleiro do time dos professores/Cruzeiro e a torcida dos alunos/Atlético foi ao delírio. Tantos gritos e "gozaçóes" intimidaram os professores. Nesse jogo a derrota dos professores foi dupla: perdedores do jogo e amplamente caçoados pelo público (em sua maioria de alunos), o gol da aluna foi recebido como uma humilhação. Como afirma Damo (2005, p. 166):

as alegaçóes de que "as meninas não sabem jogar" e de elas "avacalham o jogo" devem ser compreendidas a partir de uma noção mais alargada de jogo, no sentido de que, para além do futebol ou de outra modalidade qualquer, existe um jogo de status ou, se preferirem, um operador simbólico em ação. O que está em jogo no futebol dos meninos é, basicamente, sua honra pessoal - a coragem e a virilidade, sobretudo ainda que elas sejam seguidamente implícitas.

Poucas mulheres se aventuravam a romper as fronteiras de gênero. Por outro lado, uma 
vez jogando com mulheres, os homens eram obrigados a assumir os riscos de serem desqualificados. A participação feminina no futebol constituía uma ameaça: de mudança do sentido do jogo, destituindo-o da conotação masculina; de desqualificação do desempenho masculino, caso uma mulher apresentasse habilidade superior à do homem no jogo. Se um menino driblasse uma menina, não teria feito "nada além do óbvio", mas, se viesse a ser driblado, seria "caçoado por seus pares" (Damo, 2005 , p. 159). Sobre o risco de jogar com mulheres e, principalmente, de "levar gol de menina”, Schiva (um jovem de 17 anos) afirma: "É pesado, é pesado, é triste, é sofrido. [...] Porque as meninas já não são muito boas de bola, ainda você toma um gol pra elas aí é triste. [...] Humilhação pesada. É melhor tomar um gol pra um menino novinho do que pra uma menina velha, porque não tem jeito não, mulher”.

$\mathrm{Na}$ observação dos raros momentos de participação simultânea de mulheres e homens nas práticas de futebol nas aulas de Educação Física, fui compreendendo as tensóes e os riscos a que os jovens ficavam expostos com a participação feminina. $\mathrm{O}$ trecho do diário de campo que segue é apenas uma das muitas situações ocorridas na escola:

[...] A professora encerra o jogo dos meninos informando aos jogadores que é a vez das "meninas". Assim, pede que elas organizem os times e que eles desocupem o espaço. Enquanto o grupo se organiza, a professora permite que os jovens saiam da quadra para beber água. Os times femininos são formados a partir de convocaçóes do grupo. As jovens chamam insistentemente as colegas para participar do jogo. Há algumas adesões, mas muitas jovens permanecem na arquibancada. Demora um pouco até que os times sejam formados (4 meninas e 1 menino no gol). Iniciado o jogo, imediatamente percebo a diferença de ritmo: o jogo das meninas é menos corrido do que o anterior, dos meninos, e tem menos choques e rivalidade entre as jogadoras. Poucas jovens têm domínio da bola nos pés e, desse modo, são inevitáveis as saídas de bola pela linha lateral, paralisando o jogo. $\mathrm{O}$ jogo permanece por um tempo, sem que as meninas consigam acertar passes e fazer chutes a gol.

Os jovens começam a voltar para a quadra. Alguns comentam sobre os problemas e lances importantes do jogo de futebol que acabaram de jogar. Parece até que o jogo continua a acontecer fora de campo.

A professora observa o jogo rindo de alguns lances e cobra, principalmente dos jovens, que se comportem na quadra. Na maioria das vezes, quando eles "excedem" no barulho ou nos conflitos entre si. As jovens seguem jogando sem muita rivalidade e entre muitos risos. Os goleiros fazem solicitaçóes de posicionamento ("Vai para o ataque", "Corre") e também sobre técnicas de domínio de bola. Outras vezes eles fazem indicaçóes sobre passes, apontando para quem a jogadora deve passar a bola.

$\mathrm{Na}$ arquibancada, as jovens que optaram por não participar ficam alheias ao jogo de futebol. Estáo fazendo tarefas escolares e conversando. Diferentes delas, eles não perdem um lance. Assim, comentam algumas jogadas em alto tom e interferem em outras ("Chuta rasteiro"; "Cabeceia”...).

O jogo já não se dá apenas entre os times dentro da quadra. Acontece que os jovens que estáo na arquibancada participam dele comemorando os gols com gritos e risos. Enquanto os times que estão jogando buscam o êxito, na forma de gol no time adversário, os jovens da arquibancada iniciam um jogo “intermediário”. Não importando qual time está ganhando, eles torcem para que as "meninas" consigam fazer gols em seus colegas (os goleiros). Quando o gol acontece, a farra é geral. Muitos gritos, comemorações e, principalmente, chacotas ao goleiro "vazado". A interferência dos jovens no jogo é visível: eles 
incentivam as jogadoras a chutar cada vez mais para o gol e a driblar os goleiros. Elas passam a tentar mais o gol e, com isso, aumenta o número de gols no jogo. Os goleiros parecem se dividir entre a defesa do gol e as chacotas dos colegas ( $p$ arecem menos concentrados). O jogo segue, cada vez mais, envolvendo jogadores e "torcedores".

A professora encerra a aula pouco antes do sinal de recreio.

Como em outros contextos brasileiros, a participação feminina nas práticas futebolísticas não se dava de forma "natural" e tranquila. Exigia, ao contrário, de homens e mulheres a superação de barreiras, a aceitação de certos estigmas e dos riscos que envolvem esse tipo de jogo. Nesse caso, o que estava em questão eram as identidades. Para Lave e Wenger (1991, p. 116), o processo de participaçáo/aprendizagem de uma prática social envolve "o risco de iniciar o estabelecimento da identidade". No caso do futebol essa era uma questáo central: conflitos entre o desejo de participar e o medo de mudança também cercavam o universo de produção desse esporte. É importante salientar ainda que a participação da professora na aula de Educaçáo Física não difere muito da do professor nesse mesmo contexto. Mesmo que o professor tivesse maior legitimidade para participar/ensinar o futebol, a singularidade do futebol é que ele acontece (ou se produz) cotidianamente na escola de maneira independente em relação às práticas de ensino, inclusive na Educação Física. Afinal, como dizem os alunos nas aulas: "É futebol? Então solta a bola, professor".

Enquanto, na escola, as mulheres, de certo modo, tinham penetração e tencionavam a produção do jogo, fora dela esse tipo de conflito náo existia. No cotidiano do bairro, a ampla e intensa participação masculina no jogo contrastava com a ausência das mulheres não só como praticantes do futebol, mas também dos contextos de sociabilidade produzidos no seu entorno. Se a significação do futebol na escola remetia "automaticamente" ao masculino, no campo de futebol, na Praça de Esportes e nas ruas do bairro essa significação ganhava mais força.

No bairro pesquisado, a "falta" de habilidade da maioria das mulheres no futebol estava, portanto, diretamente atrelada à dificuldade de participação no jogo. Tendo em vista que a habilidade futebolística é constituída do engajamento na prática social, para participar dela, entretanto, era necessário ser admitido como iniciante (ou ter acesso à participação periférica, nas palavras de Lave e Wenger, 1991). Enquanto ser do sexo masculino era suficiente para tornar os jovens participantes em potencial do futebol, o mesmo não acontecia com as jovens (que não eram consideradas iniciantes). A falta de legitimidade feminina para participar do jogo não possibilitava às mulheres um tipo de envolvimento que lhes permitisse aprender. Das que conseguiam a participação, a maioria o fazia no contexto escolar. Era como se na escola ("que não é o mundo de verdade") as jovens pudessem experimentar uma prática do universo masculino - o que não significava participar desse universo de prática ${ }^{13}$.

Para se tornar participante periférico do futebol (que, conforme Lave e Wenger, 1991, é o que permite o engajamento/aprendizagem,) o mais básico requisito era ser do sexo masculino ${ }^{14}$. Assim, um rapaz podia até se considerar sem aptidão para o jogo, mas jamais sem legitimidade de participação. Nas relaçôes cotidianas de futebol, obter legitimidade de participação era, portanto, mais importante que obter o ensino ou até mesmo legalidade. Segundo Costa (2006, p. 118), no Brasil, “o medo da masculinização foi uma das principais motivações para que, em 1941, através do Decreto-Lei no. 3199", a prática do futebol feminino fosse proibida. "Esse perigo era inaceitável 
para uma sociedade que entendia que as mulheres deveriam ser 'belas, maternais' e femininas”. Na década de 80, o futebol feminino (sob pressão) foi oficializado no país (Costa, 2006). Sem legitimidade, entretanto, a legalidade não garantiu a participação feminina no futebol. Como afirma Costa (2006, p. 126):

Não é verdade que mulher naturalmente não se interesse por futebol ou naturalmente não saiba jogar futebol. Também não é verdade que futebol seja coisa de homem. Mas muitas mulheres ouviram e até reproduziram essas assertivas durante muito tempo, porque a configuração tanto simbólica quanto concreta dos espaços ocupados pelo futebol pertence, primordialmente, aos homens.

Lidar com as questóes que envolvem a produção desse esporte exige, contudo, ultrapassar o limite da denúncia da dominação do feminino pelo masculino e retomar o debate sobre o conceito de gênero proposto por Scott (1995). Para Scott, "o termo gênero não implica necessariamente uma tomada de posiçáo sobre a desigualdade ou o poder, nem tampouco designa a parte lesada (e até hoje invisível)" (1995, p. 75). A autora afirma que o termo gênero "é também utilizado para sugerir que qualquer informação sobre as mulheres é necessariamente informação sobre os homens, que um implica o estudo do outro". Acrescenta que o gênero rejeita explicações biológicas para "designar as relaçôes sociais entre os sexos" como forma de indicar construçôes culturais.

Essa perspectiva possibilita reflexóes interessantes sobre as práticas futebolísticas, pois permite observar que, para além da dominação masculina, há um discurso que se estabelece na educação do masculino e do feminino, ficando homens e mulheres marcados nessa relação cultural - nessa construção/educação do corpo. Se às mulheres foi negada historicamente a par- ticipação no futebol, aos homens essa inclusão foi imposta, ou seja, a identidade masculina no Brasil está, em grande medida, atrelada à intimidade com essa prática cultural. Enquanto as mulheres que constituem a habilidade futebolística são estigmatizadas ("Maria homem”), os homens que se distanciam desse modelo sofrem discriminaçóes que colocam em questão a afirmação da sua identidade masculina (homens que não jogam futebol são "maricas" ou jogam como "mulherzinha"). Assim, se o futebol é continuamente praticado, muitas vezes à exaustáo, sem que haja qualquer tipo de regulação da assiduidade, isso não se deve ao fato de que esses participantes escolhem livremente. Como prática cultural, o futebol no Brasil é "prescrito" histórico-socialmente para que meninos/jovens se tornem homens. Generificado, o exercício de aprendizagem do futebol se constitui também num exercício da masculinidade.

\section{“Vão parar de viadagem!": O futebol como exercício de masculinidade}

Toda tarde, jovens de diferentes idades que praticavam futebol na quadra da escola pela manhã se misturavam com outros praticantes no campo de futebol e na Praça de Esportes do bairro. À exceção da aula de Educação Física (quando dividiam o espaço da quadra de futebol com as alunas), no recreio da escola, no Projeto Social de futebol, no treino do time de futebol do bairro, nas práticas de lazer (na pelada), etc., os jovens dominavam o espaço. A convivência entre meninos, rapazes e homens no futebol evidenciava um complexo exercício de constituição de identidades ${ }^{15}$.

De acordo com Lave e Wenger (1991, p. 58), "a aprendizagem envolve a pessoa por inteiro", de modo que "atividades, tarefas, funções e entendimento não existem isolada- 
mente”. Segundo os autores (1991), "esses sistemas de relações surgem e são reproduzidos e desenvolvidos em comunidades sociais", de modo que a pessoa é definida por, bem como define essas relaçóes (e aprende). Para Lave e Wenger (1991, p. 53), ignorar esse aspecto da aprendizagem é negligenciar o fato de que a "aprendizagem envolve a construção de identidades" e de que "identidade, conhecimento e membro social acarretam/causam (entail) um ao outro". Como afirmam os autores (1991, p. 58), a "aprendizagem e um senso de identidade são inseparáveis: eles são aspectos de um mesmo fenômeno".

Como "arena simbólica de um ethos masculino encenado publicamente", o esporte representa para a maioria dos homens "o principal lócus de ensino, de preservação, de reatualização e de expressão pública das normas tradicionais de masculinidade" (Moura, 2005, p. 140$)^{16}$. Desse modo, ele pode ser entendido como um dos contextos interacionais de constituição de identidades ${ }^{17}$.

A convivência masculina nos espaços de futebol do bairro (para "jogar bola”, para observar as práticas, para conversar com os amigos, até para estar lá) é reveladora da importância do tipo de sociabilidade que este esporte oferecia/promovia. Como afirma Pelé (jovem de 12 anos), quem joga no campo de futebol el ou nos contextos de pelada da favela "é só homem (inclusive nas conversas sobre futebol), as mulheres gostam de brincar de bingo". Como "a casa-dos-homens" descrita por Welzer-Lang (2001, p. 462), trata-se de contextos "onde a homossociabilidade" podia ser vivida e "experimentada em grupo de pares" - quando os mais velhos mostravam, corrigiam e serviam como modelo para aqueles que buscavam acesso à virilidade ${ }^{18}$.

O universo do futebol é, portanto, um lócus "especialmente apto para oferecer à comunidade masculina espaços, atores, ações e práticas condizentes à produção e reprodução de um ethos" e de conjunto de emoçôes que se constituem culturalmente como um tipo de educação masculina (Binello; Conde; Martinez; Rodrigues, 2000, p. 39). O futebol é, desse modo, contexto onde não apenas impera a presença masculina, mas também onde os comportamentos (hegemônicos) associados à masculinidade são ressaltados. Conforme foi observado no bairro, nesses contextos eram corriqueiras as situaçóes de brigas (pequenos conflitos ou "estranhamentos" entre jovens/ jogadores), empurróes, choques, palavróes o que, afinal, como afirmou Juliano (auxiliar do treinador), "é inevitável, principalmente na hora do jogo”. A exaltação desses modos masculinos (ou que na sociedade/cultura são associados à masculinidade) permite que o futebol seja visto não só como específico para a sociabilidade dos homens, mas também como "proibido" para as mulheres.

Era tão significativa a distinção de gênero nessas práticas futebolísticas que a participação de mulheres parecia destoar da lógica do lugar. "Frágeis" (como diziam os praticantes quando se referiam às mulheres), elas pareciam inadequadas para contextos sociais de convivência dos homens e de exaltação de valores e modos masculinos. No relato que segue, esses contextos de futebol podem ser entendidos como masculinos:

Combino com Biruga (o treinador do time Infantil e Juvenil do bairro) para frequentar os treinos, peladas e jogos do grupo. Desse modo, no horário informado por ele, vou para o campo de futebol do Racing a fim de acompanhar um dos treinos.

Chego antes das 16h (horário marcado para os treinos) e já estão lá alguns jovens (que não fazem parte do time) "batendo bola" em uma parte do campo. Do outro lado, Biruga conver- 
sa com os jovens/jogadores do time. Ele parece estar fazendo uma daquelas reunióes de rotina (para "chamar o time à responsabilidade" nos treinos).

Vou chegando devagar e, logo que Biruga percebe a minha presença, acena com a cabeça consentindo a minha aproximação. Muitos jovens estão sentados no banco de madeira, outros de pé ouvem Biruga (enquanto observam a minha chegada). Paro ao lado de Biruga. A princípio não entendo muito bem a conversa, apenas que ela funciona como um tipo de reforço, para invocar a seriedade da participação no treino/time. Biruga afirma que os jovens devem aproveitar a oportunidade, pois podem ser substituídos.

Após conversa (de uns 10 minutos aproximadamente), Biruga me apresenta aos jovens do time. Diz que eu estou fazendo uma matéria sobre o futebol e que vou acompanhar o grupo por um tempo. Fala também que eu devo ser formada em alguma coisa (confirmação de que mereço respeito ou credibilidade para meu trabalho). Biruga avisa ainda aos jovens que eles estão na presença de uma mulher ("Que deveria ser casada".) e que não é para eles xingarem palavróes ou falar besteira no decorrer do treino: "Nada de palavróes hoje”. Finalmente, avisa aos jogadores que Juliano e outro jovem vão assumir o treino, pois ele está fazendo um curso. Já de saída do campo, Biruga se dirige a mim dizendo: "Você fica por aqui" (referindo-se ao lado do campo em que devo ficar para fazer as observaçóes). Ele acrescenta: " $L a ́$ (apontou para o outro lado), eu não aconselho". Deixa implícita a falta de segurança do lugar próximo à arquibancada, onde estão sentados alguns jovens que "usam" drogas. Biruga pede que eu o siga e se dirige para dentro do campo. Antes de sair, organiza os times de futebol para o jogo/ treino, convoca os jogadores de cada time falando as posições. Biruga dá as últimas instruçôes a Juliano e atravessa o campo em direção às arquibancadas. Mesmo à distância, ele continua a dar orientaçóes ao grupo e a Juliano. Somente após estar muito longe sai totalmente de cena. Juliano dá início ao jogo apitando.

Constituindo a si próprios na prática social, os jovens do bairro produziam futebol e masculinidades. Do mesmo modo, jovens que ficavam sempre em grupos de mulheres eram estigmatizados e tinham a masculinidade questionada. Isso foi o que ocorreu com Joaquim, jovem de 14 anos que participava de um grupo de meninas na escola. Associado à feminilidade, ele não era chamado para jogar com os homens (a praticar a masculinidade). A sua forma de inserção no futebol (jogando apenas com mulheres) parecia deixá-lo à margem do universo simbólico do futebol e da masculinidade hegemônica.

Para Welzer-Lang (2001), não se chega a ser macho sem passar grande parte do tempo em "espaços masculinos". Segundo o autor (2001, p. 465), "os homens que não mostram sinais redundantes de virilidade" (participando das práticas futebolísticas com outros homens, por exemplo) "são associados às mulheres e/ou a seus equivalentes simbólicos" (os homossexuais) e, portanto, estigmatizados. Foi o que ocorreu com Joaquim e outros jovens que no bairro fugiam da participação nesse tipo de prática social ou que aderiam à participação em práticas mais associadas ao âmbito do feminino. Por exemplo, participar dos jogos de queimada com as meninas da escola nas aulas de Educação Física como fazia Joaquim ${ }^{19}$. Afirma o autor (2001, p. 468): "nós estamos claramente na presença de um modelo político de gestão de corpos e desejo" em que o "aprender a estar com homens [...], aprender a jogar hockey, futebol ou baseboll é inicialmente uma maneira de dizer: eu quero ser como os outros rapazes”. Portanto, "eu quero me dissociar do mundo das mulheres e das crianças” (Welzer-Lang, 2001, p. 463).

Quanto mais distante do feminino, mais o jovem demarcava a sua masculinidade. As- 
sim, definir-se como homem era se distinguir das mulheres ${ }^{20}$. É por isso que no decorrer das práticas futebolísticas no bairro eram muitas as intervenções que visavam à demarcação das açôes "adequadas" ao sexo masculino. A educação dos jovens nas práticas futebolísticas estruturava o masculino de maneira paradoxal e produzia nos pequenos homens a ideia de que, para serem homens de verdade, deviam "combater os aspectos que poderiam fazê-los serem associados às mulheres" (Welzer-Lang, 2001, p. 426). Assim, praticantes (sobretudo os mais velhos) se dirigiam aos jovens encorajando-os a assumir posturas/modos masculinos e desencorajando-os (e até proibindo-os) de condutas impróprias. Isso foi o que ocorreu, por exemplo, quando dois jovens (que aguardavam a vez de realizar o exercício de futebol proposto pelo professor do Projeto Social) começaram a brincar muito próximos, realizando até pequenos toques corporais (um segurando o outro). Imediatamente, ao perceber a movimentação desses jovens, o professor os advertiu em voz alta: "Vão parar com viadagem!" A intervenção chamou a atençáo da turma, que logo se voltou para os dois "infratores" dos códigos masculinos. Eles encerraram a brincadeira, enquanto o professor se aproximava, completando: "Homem não fica pegando assim não. Isso é coisa de mulher".

O esforço de diferenciação estava contido, entretanto, no próprio gesto futebolístico e no investimento de aprendizagem/participação no futebol. Afinal, na cultura em que o futebol se constituiu historicamente como prática/ atribuição masculina, o domínio do jogo em

\begin{tabular}{|c|c|}
\hline $\begin{array}{l}\text { Jovens do sexo masculino } \\
\text { (que aprenderam ou estavam aprendendo o jogo) }\end{array}$ & Jovens do sexo feminino \\
\hline $\begin{array}{l}\text { - Chegavam ao espaço, organizavam e iniciavam o jogo ra- } \\
\text { pidamente. } \\
\text { - Paravam muito raramente o jogo para discutir as regras. } \\
\text { - Realizavam jogos (com raras exceções) competitivos, dinâ- } \\
\text { micos/corridos, viris e agressivos. } \\
\text { - Encenavam, nos confrontos/choques entre os jogadores, } \\
\text { quedas/manhas de jogadores profissionais. } \\
\text { - Faziam geralmente comemorações de gol silenciosas, com } \\
\text { toques de mãos fechadas. } \\
\text { - Para chamar a atenção dos parceiros batiam palmas, asso- } \\
\text { viavam e produziam outros sons com a boca. } \\
\text { - Tinham mais intimidade/desenvoltura no manuseio da bola } \\
\text { de futebol. Olhavam menos para a bola e mais para os outros } \\
\text { jogadores na hora do passe e recebiam a bola escorando-a } \\
\text { com a parte interna/externa do pé. } \\
\text { - Recebiam o passe/bola com abordagem direta. } \\
\text { - Recorriam mais frequentemente à habilidade para manter/ } \\
\text { conseguir posse de bola no jogo. } \\
\text { - Insistiam mais em alcançar bolas longas (vigor para o jogo, } \\
\text { superação de limites). } \\
\text { - Consideravam errar chutes (ou, como diziam os nativos, } \\
\text { "chutar vento") motivo para chacotas. }\end{array}$ & $\begin{array}{l}\text { - Demoravam a organizar o time e iniciar o jogo, pois tudo era mais } \\
\text { conversado. } \\
\text { - Paravam o jogo muitas vezes para discutir as regras. } \\
\text { - Davam ao jogo geralmente um tom de brincadeira, com ritmo } \\
\text { menos intenso, com menos rivalidade e competição. } \\
\text { - Gritavam (com expressão de dor), nos confrontos/choques entre si. } \\
\text { - Faziam comemoração de gol com gritos, pulos e abraços entre si. } \\
\text { - Chamavam a atenção das parceiras tratando-as pelo nome ou } \\
\text { gritando ("Aqui. Aqui."). } \\
\text { - Tinham menos intimidade/desenvoltura no manuseio da bola de } \\
\text { futebol e, às vezes, até pareciam ter medo dela. Quase não tinham } \\
\text { domínio de bola nos pés e apresentavam dificuldade para abordar } \\
\text { a bola em movimento. Ficavam mais emboladas no campo (onde } \\
\text { estava a bola estavam todas as jogadoras). } \\
\text { - Recebiam passes muitas vezes, titubeando sobre a forma de } \\
\text { abordar a bola. "Sapateavam" na escolha do pé a tocar a bola, pre- } \\
\text { feriam os "bicudos" (chutar com o dedão), olhavam para a bola, } \\
\text { chutavam em direções menos precisas, recebiam passes pisando } \\
\text { na bola (movimento de cima para baixo - forma de apreensão de } \\
\text { pouco sucesso). } \\
\text { - Usavam mais a força para manter/conseguir a posse de bola, va- } \\
\text { lendo empurrar, segurar, gritar. } \\
\text { - Desistiam de correr nas bolas "longas" (mais frequentemente) } \\
\text { esperando a saída lateral. } \\
\text { - Consideravam errar chutes ("chutar vento") motivo de risos. }\end{array}$ \\
\hline
\end{tabular}


si já "atestava” masculinidade e/ou funcionava como um investimento nela. Não se pode, contudo, dizer que o feminino estava ausente. Pelo contrário, o feminino apresentava-se como uma referência a se opor.

Observando os jogos de futebol na aula de Educação Física na escola (único contexto em que mulheres jogavam futebol no bairro) foi possível fazer um inventário das práticas de futebol de alunos e alunas. Nesse exercício, foi possível destacar, para além das semelhanças, algumas singularidades que caracterizavam os modos de jogar/agir de homens e de mulheres no jogo - o que está diretamente relacionado com os valores e normas sociais presentes neste esporte e com as condiçóes de acesso/aprendizagem, mas não com esquemas inatos.

$\mathrm{Na}$ tabela da página anterior sáo descritos traços hegemônicos do futebol nas aulas de Educação Física da escola.

Primeiramente, é importante salientar que algumas das características do futebol descritas como parte do modo de agir das mulheres também foram observadas entre os iniciantes. Contudo, eles não foram incluídos no grupo pelo fato de que, ao contrário das meninas, que seguiam realizando práticas de futebol semelhantes no decorrer de toda a escolarização (jovens de $5^{\mathrm{a}}$ série jogavam de forma semelhante às do $\left.2^{\circ} \mathrm{grau}\right)$, quase todos eles mudavam muito rapidamente a forma de jogar, aprendendo/ incorporando o jogo. Sobre esse conjunto de dados é importante ressaltar também que a aprendizagem do futebol envolvia mudanças na forma de agir (no modo de jogar, no modo de organizar os jogos, no modo de comemorar o gol, no modo de se comportar em campo de jogo, etc.), de significar e de sentir o jogo.

$\mathrm{Na}$ escola, os praticantes que pretendiam se diferenciar das mulheres realizavam exaustivamente o jogo. Quanto mais o modo de jogar se aproximava da "forma como as mulheres" (ou iniciantes) jogavam, maior era a chance de ser alvo de chacotas ("Você joga que nem mulherzinha"). Isso era também o que acontecia com aqueles que não apresentavam um tipo de vigor para o jogo. Um exemplo: quando os jogadores do time de futebol manifestavam medo (ficando titubeantes) nas situaçóes de "dividida", o treinador dizia: "Alguns jovens jogam como moça! Joga igual homem, porra!". No futebol, como afirma Oliveira (2004, p. 261), exige-se dos jogadores:

[...] assumir uma postura corporal mais rígida em situaçóes em que se queira mostrar-se inabalável, negar-se a assumir alguns sentimentos tidos como não masculinos, reagir a desafios lançados por outros homens, desafiar outros homens, debochar e zombar de colegas por comportamentos e atitudes supostamente pouco masculinas.

Quanto às mulheres (que não deviam jogar como homens), elas podiam por vezes participar do jogo, desde que passassem despercebidas, desde que não apresentassem habilidade que pudesse remetê-las ao âmbito do masculino ou não disputassem espaço com os homens. Portanto, jovens que se habilitavam (aprendiam) no futebol deviam mostrar-se masculinos, enquanto com as mulheres ocorria o inverso. Em síntese: mulheres "que jogam quase como homens" e "homens que jogam como mulheres" eram estigmatizados. De outro modo, é preciso considerar que a prática futebolística também tencionava os padróes culturais produzindo diferentes masculinidades (com os jovens que não se interessavam pelo jogo) e feminilidades (com as jovens que se produziam mulheres nesses contextos). Segundo Connell (1995, p. 190), a construção da masculinidade "tem uma estrutura dialética" e não mecânica. Tal como afirma o autor (1995, p. 189), "diferentes masculinidades são produzidas no mesmo contexto social", ou seja, "as relações de gênero incluem 
relações entre homens, relaçóes de dominação, marginalização e cumplicidade”. Enfim, "uma determinada forma de masculinidade tem outras masculinidades agrupadas em torno dela”.

Articulando o ônus (dores do corpo, exposição pública, etc.) e o bônus de participar da prática social masculina - o "prazer de estar entre homens ou homens em formação, de se distinguir das mulheres, prazer de poder legitimamente fazer como os outros homens" (Welzer-Lang, 2001, p. 463), de pertencer à comunidade de prática (Lave; Wenger, 1991) -, cada jovem/homem ia individual e coletivamente constituindo a masculinidade. Mas não se tratava de um processo ausente de coerções sociais. Afirma Nogueira (2006, p. 231):

Os meninos, portanto, encontram-se duplamente marcados por essa exigência de se tornarem homens: (1) por serem jovens, assim como as meninas, e terem que corresponder aos ideais sociais estabelecidos para a maioridade [...]; (2) por serem impúberes em sua juventude e terem que adquirir, não apenas os caracteres sexuais secundários, mas a pilosidade mais abstrata, mas não menos material, de uma masculinidade incontestável e a mais próxima possível à hegemônica.

Nas práticas futebolísticas, portanto, cada praticante era guardião dos "modos masculinos", repassados com palavras (como fez o professor do Projeto Social), mas sobretudo em gestos, posturas, poses, modos de agir. Era no "paralelismo dos corpos" suados, viris, competitivos que cada jovem futebolista ia aprendendo a compor o próprio corpo como corpo masculino. Como afirma La Cecla (2005, p. 102), "ser varão com outros varôes significa saber jogar este jogo de regras não escritas”, isto é, "os homens ficam juntos para definir a sua própria masculinidade”. Masculinidade que se "adquire por imitação" e num processo de aprendizagem contínuo (2005, p. 105), “como corpo que imita a outros ao redor" (2005, p. 28). No bairro, esse tipo de educação feita por mimetismo ocorria em todos os contextos de futebol: quando os jovens imitavam os dribles e peripécias dos jogadores profissionais e/ ou os modos de agir, os gestos e as poses corporais dos veteranos; quando eles imitavam a coragem daqueles que não "amarelavam" (se acovardavam) nos desafios e nos momentos de tensão/embates do futebol, etc.

Situando o exercício da masculinidade nos contextos de aprendizagem esportiva, Guedes (1998) apresenta elementos da prática futebolística que também estavam presentes no bairro. Segundo a autora (1998, p. 132-133), é da "tematização dos confrontos através do corpo" e dos "sucessivos embates" - "em que se aprende a atacar e recuar, a náo aceitar provocaçóes, sendo, ao mesmo tempo duro" - que se aprende um "modo de ser homem". Em vista disso, era da "batalha fingida" do futebol na escola, no campo de futebol, no Projeto Social e nos campeonatos amadores da cidade - em que se partia "do princípio fundamental de que só se aprende a ser homem com homens" - que se celebrava a relação entre os homens.

Pertencer ao universo futebolístico (como jogador, torcedor, colecionador de figurinhas dos times, etc.) era ingressar numa trama de relações de masculinidades que não tinha como resultado, contudo, um denominador comum. As relações de masculinidades no futebol do bairro extrapolavam também, em muitos sentidos, o campo de jogo. As práticas de torcedores, por exemplo, eram reveladoras do tipo de construçáo do masculino que o futebol envolve. Jovens que transitavam pelo bairro antes, durante e após as partidas de futebol dos times profissionais (sobretudo Cruzeiro e Atlético) faziam também dessa prática um exercício de masculinidade. Nesse contexto, críticas ao time perdedor, chacotas ("tirar sarro", como diziam 
os nativos) envolvendo os torcedores do time adversário, hinos dos Clubes, etc. eram apenas algumas das maneiras de "brincar com a virilidade do oponente". Esse tipo de zombaria e jocosidade (atrelada às situaçóes rituais do futebol) assinalava a "feminização indesejada pelos praticantes" (Nogueira, 2006, p. 213) ${ }^{21}$.

Sob o risco de estar na posição não só inferior, mas sobretudo passiva, os jovens participavam das práticas futebolísticas e demonstravam o pertencimento aos clubes esportivos. Como afirma Damo (2005, p. 100), "o clubismo e, sobretudo, os fluxos jocosos cotidianos mobilizam preponderantemente o público masculino". Nesse contexto, "pertencer é correr risco de ser insultado, gozado e passivizado". Acrescenta o autor:

Isso implica, de um ponto de vista posicional, tornar-se ativo/passivo. E o que é notável: é o seu time quem lhe torna ativo ou passivo. Pela performance dele é que alguém terá o direito a fazer ou o dever de receber uma jocosidade; de gozar em ou ser gozado por alguém. Talvez por isso o sofrimento faça parte da rotina de quem se diz torcedor; dos homens em particular; afinal ser torcedor é tornar-se susceptível de vir a ser passivizado metaforicamente (Damo, 2005, p. 100).

No futebol, como se pode concluir, eram exibidas e valorizadas as demonstraçóes explícitas de habilidade, força, coragem, agilidade, virilidade, velocidade, violência, rudeza. Cuspir, por exemplo, era prática muito comum entre os jogadores no campo de futebol. Essas características eram atravessadas, entretanto, por emoções "proibidas" aos homens em outros contextos. Assim, a lágrima vinha aos olhos com a exclusão do time do campeonato, com a dor da lesão muscular, com a vitória ou derrota em um jogo decisivo e em outras situações. Sobre as emoçóes que envolvem o futebol, segue um relato de Denis (juiz de futebol):
É, e eu tava apitando o jogo lá, lotado, o campo lá de Neves. Choveu bastante e lotado o campo, mas choveu foi muito mesmo, o campo estava alagado. O time ganhou nos pênaltis... empate foi pra disputa de pênaltis, aí no vestiário, nós saímos do vestiário, e um monte de diretores do clube, [...] diretor de futebol amador, é muito interessante [...], chegou chorando pra mim dentro do vestiário (imita o choro do homem), muito obrigado, com o olho brilhando. Aquilo te emociona, aquilo você vê que seu trabalho, a responsabilidade de um árbitro de futebol é muito grande.

Como espaço do masculino, o futebol permitia também a flexibilização de regras que regem essas relaçóes. Ao contrário de outros espaços sociais, em que os jovens do sexo masculino deviam manter a distância corporal, no momento ritual desse esporte, alguns tipos de contatos masculinos não só eram permitidos como também desejáveis. Os jogadores, por exemplo, ficavam abraçados em algumas situações de jogo (na oração, no grito de guerra, na hora da cobrança de um pênalti...). Eles se tocavam nas comemoraçóes de gol: toque de mãos, abraços, carregar no colo o autor de um gol importante. Muitas vezes, quando o autor do gol se deitava ao chão, "todo" o time podia ir deitando em cima dele, um verdadeiro amontoado de homens, uns sobre os outros. Esse tipo de toque corporal não colocava em questão a masculinidade. Como afirma Damo (2005, p. 103), o futebol é também uma "modalidade particular de sociabilidade", em que são "culturalmente toleradas, senão obrigatórias" as "expressóes públicas de afetos masculinos". Contudo, o jovem ("aprendiz de homem") devia saber se situar nesse campo de relaçôes, desvendando os limites colocados aos toques e as circunstâncias em que eram permitidos. Esse aprendizado, feito a "duras penas", constituía também um exercício de identificação com os pares e de distinção do feminino. 
80 $\mid$ Eliene Lopes Faria

Todo o processo de participação/aprendizagem na prática social permite compreender que o jogo de futebol constituía o corpo do praticante como corpo masculino e que o corpo do praticante constituía o jogo de futebol como jogo masculino. De forma circular e imbricada, um ia produzindo o outro. No futebol os jovens do bairro iam adquirindo aquilo que La Cecla (2005) chama de fisionomia masculina (que os fazia parecer nascidos para o jogo). Por isso é que o autor (p. XIV) afirma que "as identidades sexuais são fisiologias transformadas em fisionomias".

Essa circularidade de significados acabava por tornar a habilidade futebolística "inacessível” às mulheres. Assim, eram comuns declaraçóes semelhantes a esta: "As mulheres jamais jogam como os homens". Conforme afirmaram Izaque (que relata sobre uma colega habilidosa) e Denis, o jogo era visto como patrimônio masculino:

Izaque - Ah, ela joga muito veio. Joga quase igual homem mesmo.

Eliene - O que que é diferente? Que num joga igual homem?

Izaque - Ah, porque ela é mulher também no caso... e qualquer coisa, tipo assim a gente trombar nela, num aguenta, porque nós homem trombar nela ai ela num vai aguentar, mas mulher ai ela aguenta. E ela deita o cabelo. Dibra pra caramba. Faz gol. Mete o gol. Mete a gaveta. (grifos meus)

Você pega uma seleção brasileira masculina jogando e a seleçáo brasileira feminina jogando e você vai ver a diferença, que é a mesma coisa de escola, se você for comparar, é a mesma coisa do homem jogando, só que ela tem habilidade, técnica, sabe tocar, correr, mas é diferente dos homens. (Denis - Professos de Educação Física) (grifos meus)
A percepção dos modos de jogar futebol como modos masculinos parece náo apenas distinguir, mas também homogeneizar homens e mulheres. Mas havia contrastes: mulheres que jogavam melhor que alguns homens e homens que não sabiam jogar futebol. Mesmo assim, não serviam como parâmetro flexibilizador destas certezas: "futebol é coisa de homem"; homem é que detém o domínio da habilidade para o jogo. Ocorria desse modo, no bairro, uma naturalização do futebol como prática masculina ${ }^{22}$. O jogo de corpo no futebol (historicamente adquirido, porém interpretado pelos praticantes como natural) nesse contexto cultural se constitui como jogo de corpo masculino.

As identidades de gênero eram assim tecidas e incorporadas pelos praticantes na prática social. Como afirma Connell (1995, p. 189), "no gênero a prática social se dirige aos corpos”, ou seja, "as masculinidades são corporificadas, sem deixar de ser sociais". Segundo o autor (1995, p. 189), "nós vivenciamos as masculinidades (em parte) com certas tensóes musculares, posturas, habilidades físicas, formas de nos movimentar, e assim por diante".

Parte de um jogo complexo, as masculinidades exercitadas nas práticas futebolísticas não se produziam, contudo, de forma mecânica. Como afirma La Cecla (2005, p. 60), "o gênero é uma prática, ou seja, algo que se modela com a prática". Assim, "ser homem ou mulher é uma técnica do corpo no sentido de Mauss, porém uma que nos precede biograficamente, uma técnica de presença no mundo", ou seja, "ser homem ou mulher não é uma inscrição biológica, senáo como temos dito, uma condição" ${ }^{23}$ :

Condição é um condicionamento e ao mesmo tempo uma faculdade, uma atitude. Uma condição pressupóe uma herança e um exercício, um "a partir" e um desenvolvimento, um 
ser precedido por algo e um estar destinado a ele, sem que estas linhas signifiquem um impedimento para a articulação inédita do presente (La Cecla, 2005, p. 13).

\section{Algumas consideraçóes}

No universo pesquisado, somente os jovens do sexo masculino têm amplo acesso à prática. Contudo, se o futebol é continuamente praticado, muitas vezes à exaustão, sem que haja qualquer tipo de regulação da assiduidade, isso não se deve ao fato de que esses participantes escolhem livremente. Como prática cultural, o futebol no Brasil é "prescrito" histórico-socialmente para que meninos/jovens se tornem homens. Generificado, o exercício de aprendizagem do futebol se constitui também num exercício da masculinidade.

Espaço do masculino - e, portanto, de veiculação de modelos hegemônicos de masculinidade a serem aprendidos nas relaçóes entre meninos, jovens e homens - nos contextos de produção do futebol exaltam-se qualidades, como força, destreza, astúcia, virilidade, agressividade, e um misto de respeito à regra e insubordinação. Portanto, o jogo de futebol é uma prática "mediante a qual se aprende a ser corpo masculino", num processo de aprendizagem contínua (La Cecla, 2005, p. 105). Assim, o jogo envolve um tipo de pertencimento/identificação e os jovens exercitam também discursos sobre o corpo repletos de padróes hegemônicos - o que não significa homogeneidade.

Enfim, a aprendizagem do futebol engloba mais que técnicas. Envolve a incorporação de formas de agir, de movimentar o corpo e, com elas, um conjunto de aspectos implícitos (referentes à dimensão identitária, à prática coletiva, a significados, a certos valores e disposiçôes). Envolve a constituição da habilidade no sentido proposto por Ingold (2001): gestos, significados, tipos de atenção, emoçóes, disposiçóes corporais, identidades, etc.

\section{Game-body, body of the game: football and masculinity}

abstract The object of this text are football practices as contexts in which gender identity is learned. Developed based on an ethnographic foray into the football routine of youths in a neighborhood of Belo Horizonte, this article discloses important issues (in the learning process) involving the formation of masculinity and the gender relations at stake in this sport. Thus, it reveals that the learning of football is widespread in the different ways of participating in social practice and involves more than techniques, tactics and rules. In daily football practices, young athletes learn football and also build identities. It is not, however, a process of passive assimilation in which the body is gradually molded. On the contrary, the culture of football marks the body of its players just as it is marked by them.

keywords Football. Learning. Gender. Identity. Masculinity.

\section{Notas}

Marca da modernidade e sinônimo de sofisticação, o futebol chegou ao Brasil como promissor atrativo das elites. Não era acessível a qualquer um, mas somente aos iniciados em seus princípios e saberes técnicos (sportmen), que desfrutavam de tempo livre para desenvolvê-lo. Assim, afastavam-se do direito a essa prática os trabalhadores manuais, operários e negros (Pereira, 2000). Mas o futebol não ficou confinado às elites brasileiras, passando rapidamente a ser praticado "também em outros campos pelos negros, pobres e trabalhadores" (Pereira, 2000, p. 87). Longe do ideal de controle pretendido, foi se disseminando por todo o país. Transformou-se rapidamente em fenômeno de massas. O fute- 
bol é hoje o esporte mais praticado no mundo. No Brasil não é diferente. Denominado como país do futebol (e também do carnaval e do samba), esse esporte há muito deixou de ser uma prática à margem na cena nacional. É, de fato, intrigante a difusão do futebol no país. No doutorado, interessei-me particularmente em explicitar as práticas de aprendizagem que permitem a (re)produção/difusão do futebol.

2 A aprendizagem como "atividade situada" constitui a definiçáo central do processo que Lave e Wenger (1991, p. 29) chamam de Legitimate Peripheral Participation (LPP), ou seja, processo pelo qual aprendizes participam em comunidades de prática em que o domínio do conhecimento e das habilidades requer movimento em direção à "participação plena nas práticas socioculturais". Apostando na necessidade da visão relacional da pessoa e da aprendizagem, Lave e Wenger (1991, p. 54) acreditam que é importante construir uma "noçáo robusta da pessoa por inteiro", fazendo justiça às "múltiplas relaçóes através das quais ela define a si mesma na prática”. A ênfase está nas relaçóes entre produção de identidades e produção da comunidade de práti$\mathrm{ca}$, o que permite entender que a aprendizagem incorpora, embora de modos transformados, a característica estrutural da comunidade (p. 56). Afirmam também que o "desenvolvimento da identidade é central para as carreiras de novatos (newcomers) na comunidade de prática e, assim, fundamental para o conceito de LPP” (p. 115).

3 A juventude não é uma categoria homogênea. Como afirma Melucci (1997, p. 9), "a juventude não é mais somente uma condiçâao biológica, mas uma definição cultural". Constituída pela faixa entre 15 a 24 anos nas orientaçóes de trabalhos na área demográfica, essa classificação de juventude é questionada por Spósito (1997, p. 39), que afirma que "[...] para o conjunto da sociedade brasileira, a tendência maior é a antecipaçáo do início da vida juvenil para antes dos 15 anos, na medida em que certas características de autonomia e inserção em atividades no mundo do trabalho - típicos do momento definido como a transição da situação de dependência da criança para a autonomia completa do adulto torna-se horizonte imediato para grande parcela dos setores empobrecidos". A partir das reflexôes apresentadas por Spósito (1997), torna-se possível afirmar que a categoria juventude não é estável e linear, mas histórica. Assim, a juventude não é um dado. Ela é, antes de tudo, uma construção carregada de significação cultural, bem como os jovens são plurais (juventudes) e contrariam um conjunto de estereótipos a eles atribuídos tais como: irresponsabilidade, impetuosidade desmedida, violência, desapegos aos valores familiares.

4 A opção por investigar as práticas de futebol de jovens da periferia da cidade tornou-se relevante, primeiro, porque os jovens em idade de escolarização têm intensificação do acesso às práticas esportivas/futebolísticas nas aulas de Educação Física e ampliaçáo da sua vivência em outros tempos escolares (recreios, entradas e saídas da escola) e sociais (fora da escola). Além disso, porque na periferia (ao contrário dos bairros mais centrais de Belo Horizonte) se multiplicam os espaços/tempos de produção do jogo: na escola pública (que é a que garante acesso às camadas populares), nos projetos sociais e "escolinhas" de futebol, nas peladas nas imediaçóes do bairro, nos times amadores de futebol de várzea, nas torcidas dos times profissionais de futebol, etc. O futebol é, portanto parte da sociabilidade.

Localizada na rua principal, ao lado do Posto de Saúde e do campo de futebol, a escola (estadual) pesquisada é destaque entre as construçóes do bairro. Primeiro porque não há outras escolas públicas nas proximidades. Além disso, porque tem formato oficial de construçáo escolar do Estado. São dois prédios em forma de U, com acabamento de "tijolinho à vista", ligados por um corredor que dá acesso à escada. O pátio fica entre os dois prédios e faz limite com a cantina, de um lado, com as salas de professores, secretaria, biblioteca e sala da diretoria, do outro, e também dá acesso à quadra coberta da escola. No turno da manhã, a escola recebe jovens (das séries finais do ensino fundamental e do ensino médio) que moram no bairro e imediaçóes. Nesse turno estudavam, portanto, jovens com diferentes idades (11/12 anos a 18 anos), interesses e estilos (maneiras de ser jovem) evidenciados nas formas de agir, vestir, de ocupar o espaço escolar e de se envolver com a escolarização. $\mathrm{O}$ turno da tarde contempla as séries iniciais do ensino fundamental e o turno da noite, o ensino médio e a educação de jovens e adultos. 
6 Por exemplo, a linha de pesquisa da aprendizagem motora no âmbito da Educação Física.

7 Tim Ingold $(2000 ; 2001)$ propóe "a noção de cultura como habilidade" e de "aprendizagem como educação da atenção”. Para o Ingold (2001, p. 27), "o ser humano, com suas atitudes e disposições particulares, não é produto nem dos gens nem da cultura, nem de ambos juntos". Ele "é formado dentro de um processo vitalício (lifelong) de desenvolvimento ontogenético". Buscando mover-se para além "da dicotomia entre capacidades inatas e competências adquiridas" (ou entre biologia e cultura) e com foco nas "propriedades emergentes de sistemas dinâmicos", Ingold (2001, p. 114) sugere que é por meio de um "processo de habilitação (enskilment)" que "cada geração desenvolve dentro e além dos conhecimentos de seus predecessores". Isso o leva a concluir que, no desenvolvimento do conhecimento, a contribuição que cada geraçáo dá para a próxima está no desenvolvimento de um modo particular de orientação/ação/ interação em um ambiente, que o autor trata como educação da atenção - que é equivalente a um processo de afinação/refinamento do sistema perceptual. De acordo com essa abordagem, o que se aprende e transmite às novas geraçóes não seria a cultura (somente significados), mas habilidades. Situando-se entre os que buscam na visão ecológica um "deslocamento do sujeito cartesiano, e com ele, da série de oposiçóes que inclui aquela entre natureza e cultura" (Velho 2001, p. 135), Ingold propóe a retomada da unidade original do sentido de habilidade. Para isso, a sua noçáo de habilidade considera a interaçáo entre o sujeito, os instrumentos e o ambiente. Tendo como fundamentação os estudos de Gregoy Bateson, Ingold (2001) afirma que a "habilidade, em síntese, é uma propriedade não individual do corpo (como uma entidade biofísica, uma coisa em si mesma), mas um campo total de relaçóes constituídas pela presença da pessoa-organismo" (corpo e mente) em um ambiente ricamente estruturado. A habilidade é, portanto, a capacidade de agir prontamente em relação às diferentes situações, ou seja, ela se constitui do desenvolvimento de certas modalidades de atenção para o mundo.

8 Como nos diferentes contextos de futebol do bairro os jovens eram os protagonistas das prá- ticas (ou seja, o futebol era aprendido nas interaçóes cotidianas e náo a partir de processos formais de ensino), mesmo reconhecendo a existência de algumas singularidades, optei por descrever as aprendizagens que ocorreram na escola e no campo de várzea sem estabelecer descontinuidades.

9 Oferecendo uma forma de falar sobre as relaçôes entre os novatos (newcames) e veteranos (old-timers) e sobre atividades, identidades, artefatos e comunidades de conhecimento e prática (Lave; Wenger, 1991, p. 29), a LPP é um "ponto de vista analítico sobre a aprendizagem" em que "saber/conhecer e aprendizagem são parte da prática social” (idem, p. 40). Portanto, é "proposta como um descritor (descriptor) do engajamento na prática social que acarreta aprendizagem" (idem, p. 34-35).

10 O termo gênero é utilizado para rejeitar explicaçôes biológicas, indicar as diferenças entre homens e mulheres como construçôes culturais, sugerir que qualquer informação sobre as mulheres é necessariamente informação sobre os homens. Os estudos de gênero afirmaram a primazia metodológica de investigar as relaçóes sociais de gênero sobre a investigação das concepçóes de cada um dos gêneros.

11 Bem diferente do caso de países como o Brasil, Argentina, Itália e Inglaterra, por exemplo, "que utilizam o universo futebolístico como área reservada à masculinidade", nos Estados Unidos o futebol "tornou-se área reservada feminina, reforçando a ideia de que "futebol é coisa de mulher" (Moura, 2005, p. 142).

12 Para preservar os sujeitos da pesquisa (profissionais e jovens praticantes do futebol no bairro pesquisado), todos os nomes que seguem descritos são fictícios.

13 Como se aprende Física na escola, sem ser participante do mundo dos físicos (Lave; Wenger, 1991).

14 A legitimidade da participação masculina no futebol não significava ausência total das mulheres, nem que os iniciantes iam se tornar participantes plenos da prática (o que é outra questão). Trajetórias diferentes eram constituídas nas e das práticas de futebol do bairro. Isso porque, no interior da cultura futebolística, havia múltiplos processos de enfrentamento e 
tensóes que podiam redefinir a participação e a permanência no jogo social.

15 Neste trabalho dei centralidade à constituição da identidade masculina, embora saiba que outras identidades atravessam a produçáo deste esporte: a identidade de torcedor, por exemplo.

16 Não apenas o esporte constitui a identidade de gênero: a família e a escola sáo contextos de aprendizagem do masculino e do feminino. Assim, "a compreensão da masculinidade hegemônica em contextos culturais diferentes pode envolver práticas que estão em contradição com outros espaços culturais" (Moita Lopes, 2003, p. 20-21).

17 Sem pretender ampliar a discussão, assumirei as identidades como um construto de natureza social. Como propóe Moita Lopes (2002; 2003) - que faz uma crítica às visóes essencialistas -, as identidades não têm uma base imutável que se mantém no decorrer da história. Compartilhando da posição de Hall (1996), Moita Lopes (2003, p. 27) afirma que as identidades "não são nunca unificadas”. Ao contrário, em permanente processo de mudança e transformação, "na modernidade tardia", elas "são cada vez mais fragmentadas e fraturadas, nunca singulares, mas construídas de forma múltipla nos diferentes discursos, práticas e posiçôes, frequentemente entrecruzados e antagônicos" (idem, p. 27). Como afirma Moita Lopes (idem, p. 27), a identidade "tem a ver com tornar-se e não com ser". Para o autor, aprendemos a ser o que somos nas interaçóes cotidianas.

18 Diferente dos trabalhos do antropólogo Maurice Godelier (1982) sobre os Baruya da Nova Guiné - contexto em que "a casa dos homens está materializada e localizada num lugar específico" - Welzer-Lang (2001, p. 467) usa o termo "casa dos homens" para "metaforizar os lugares de socialização masculina em nossas sociedades complexas".

19 A participação masculina nos jogos de queimada das aulas de Educação Física não necessariamente significava uma vinculação com a feminilidade. Jovens que transitavam entre homens, participando dos contextos masculinos (como do futebol) podiam por vezes participar do jogo sem que a sua masculinidade fosse questionada pelos pares.
20 Sobre a aprendizagem da masculinidade como a que envolve a aprendizagem da distinção do feminino, pode-se consultar: La Cecla (2005); Oliveira (2004); Nogueira (2006); Welzer-Lang (2001).

21 O que também observou Nogueira (2006) em seus estudos sobre a identidade juvenil. Para o autor, "o futebol também se prestava a essa mesma relação quando se tratava do enfrentamento das duas principais torcidas adversárias do estado no campeonato mineiro e nacional. Dizer que o 'Galo', símbolo do Atlético Mineiro, era uma galinha no campeonato ou que a Máfia Azul, torcida organizada do Cruzeiro, só tinha viado e que azul é cor de frutinha eram estratégias de imputar ao adversário uma condição feminina associada a seu time de futebol" (Nogueira, 2006, p. 213).

22 Alguns estudos (por exemplo, Altmann, 1998; Faria, 2001; Daolio, 1995) mostram que as mulheres, desde cedo, "aprendem" a ser obedientes, dóceis, dar atenção ao outro, perseverar nas tarefas, usar o espaço de forma limitada. Os meninos aprendem a competir, a se auto-afirmar, a usar o espaço sem economia. Nas relaçôes com o futebol essas diferenças se tornam ainda mais visíveis: os estímulos permeiam muito cedo a vida dos meninos, que, ao nascer, herdam um time de futebol para torcer, uma bola de futebol para iniciar aprendizagem, sendo todo o tempo incentivados a competir.

23 Mauss (1974, p. 211) define as técnicas corporais como maneiras com que os homens de cada sociedade "sabem servir de seus corpos" e que, não sendo naturais, mas adquiridas, expressam a própria sociedade que lhes deu origem.

\section{Referências Bibliográficas}

ALTMANN, Helena. Rompendo fronteiras de gênero: Marias (e) homens na educação física. 1998. Dissertação (Mestrado em Educação) - Faculdade de Educação, Universidade Federal de Minas Gerais, Belo Horizonte, 1998.

BINELLO, Gabriela; CONDE, Mariana; MARTINEZ, Anália; RODRIGUEZ, María Graciela. ¿Mujeres y fútbol: território conquistado o a conquistar? In: ALABARCES, Pablo (Org). Peligro de gol: estúdios sobre deporte y sociedad en América Latina. Buenos Aires: CLACSO, 2000. p. 33-55. 
CONNELL, Robert. Políticas da masculinidade. Tradução de Tomaz Tadeu da Silva. Educação e Realidade, Porto Alegre, v. 20, n. 2, p. 185-206, 1995.

COSTA, Leda Maria. Futebol e gênero no Brasil: comentários a partir do filme Onda nova. In: ALVITO, M.; MELO, V. A (Orgs.). Futebol por todo o mundo. Rio de Janeiro: FGV, 2006. p. 115-128.

DAMO, Arlei Sander. Do dom à profissionalização: uma etnografia do futebol de espetáculo a partir da formação de jogadores no Brasil e na França. 2005. Tese (Doutorado em Antropologia) - Instituto de Filosofia e Ciências Humanas, Universidade Federal do Rio Grande do Sul (UFRGS), Porto Alegre, 2005.

DAOLIO, Jocimar. Da cultura do corpo. Campinas: Papirus, 1995.

A Antropologia social e a Educação Física. In: CARVALHO, I. M e RUBIO, K. (Orgs.). Educação fisica e ciências humanas. São Paulo: Hucitec, 2001.

DORNELlES, Priscila Gomes; MOLINA NETO, Vicente. $\mathrm{O}$ ensino do futebol na escola: a perspectiva das estudantes com experiências positivas nas aulas de Educação Física em turmas de $5^{a}$ a $7^{a}$ série. In: KUNZ, E. (Org.). Didática da educação fisica 3: futebol. Ijuí: Unijuí, 2003. p. 89-131.

ENGESTRÖM, Yrjö. Developmental studies of work as a testbench of activity theory: the case of primary care medical practice. In: CHAIKLIN, S.; LAVE, J. (Orgs.). Cambridge: Cambridge University Press, 1993.

FARIA, Eliene Lopes. O esporte na cultura escolar: usos e significados. 2001. Dissertação (Mestrado em Educação) - Faculdade de Educação, Universidade Federal de Minas Gerais, Belo Horizonte, 2001.

A aprendizagem na $e$ da prática social: um estudo etnográfico sobre as práticas de aprendizagem do futebol em um bairro de Belo Horizonte. 2008. Tese (Doutorado em Educação) - Faculdade de Educação, Universidade Federal de Minas Gerais, Belo Horizonte, 2008.

GEERTZ, Clifford. A interpretação das culturas. Rio de Janeiro: LTC, 1978.

GODELIER, Maurice. La production des grands hommes: pouvoir et domination masculine chez lês Baruya de Nouvelle-Guinée. Paris: Fayard, 1982.

GOELLNER, Silvana Vilodre. Pode a mulher praticar futebol? In: CARRANO, P. C. (Org.). Futebol: paixão e política. Rio de Janeiro: DP\&A, 2000. p. 79-93.

GOMES, Ana Maria Rabelo. O processo de escolarizaçáo entre os Xakriabá: explorando alternativas de análise na antropologia da educaçáo. Revista Brasileira de Educação, Rio de Janeiro, v.11, n. 32, p. 316-326, 2006.
GUEDES, Simoni Lahud. O Brasil no campo de futebol: estudos antropológicos sobre os significados do futebol brasileiro. Niterói, RJ: Eduf, 1998.

. Um dom extraordinário ou "cozinhar é fácil, mas quem sabe driblar como Beckham?”: comentários a partir do filme Driblando o destino. In: ALVITO, M.; MELO, V. A. (Orgs.). Futebol por todo o mundo. Rio de Janeiro: FGV, 2006. p. 41-53.

HALL, Stuart. Who needs 'identity'? In: HALL, S.; DU GAY, P. (Ed.). Questions of cultural identity. Londres: Sage, 1996. p. 1-17.

INGOLD, Tim. The perception of the environment: essays on livelihood, dwelling and skill. New York: Routledge, 2000.

From the transmission of representations to the education of attention. In: The debated mind: evolutionary psychology versus ethnography. Oxford: Harvey Whitehouse, 2001.

LA CECLA, Franco. Machos: sin ánimo de ofender. Tradução de Fernando Borrajo. Buenos Aires: Siglo XXI, 2005.

LAVE, Jean. Cognition in practice: mind, mathematics, and culture in everyday life. Cambridge: Cambridge University Press, 1988.

LAVE, Jean; WENGER, Etiene. Situated learning: legitimate peripheral participation. Cambridge, UK: Cambridge University Press, 1991.

MAUSS, Marcel. As técnicas corporais. Tradução de Mauro W. B. de Almeida. In: __. Sociologia e Antropologia. São Paulo: EPU/EDUSP, v. 2, 1974. p. 209-233.

MELUCCI, Alberto. Juventude, tempo e movimentos sociais. Revista Brasileira de Educação, ANPED, São Paulo, n. especial, p. 5-14, 1997.

MOITA LOPES, Luiz Paulo. Identidades fragmentadas: a construção discursiva de raça, gênero e sexualidade em sala de aula. Campinas, SP: Mercado das Letras, 2002.

Socioconstrucionismo: discurso e identidade social. In: Discursos de identidades. Campinas, SP: Mercado das Letras, 2003.

MOURA, Eriberto Lessa. O futebol como área reservada masculina. In: DAOLIO, J. (Org). Futebol, cultura e sociedade. Campinas: Autores Associados, 2005. p. 131-147.

NOGUEIRA, Paulo Henrique Queiroz. Identidade juvenil e identidade discente: processos de escolarização no terceiro ciclo da Escola Plural. 2006. Tese (Doutorado Educação) - Faculdade de Educação, Universidade Federal de Minas Gerais, Belo Horizonte, 2006. 
OLIVEIRA, Pedro Paulo. A construção social da masculinidade. Belo Horizonte: UFMG; Rio de Janeiro: IUPERJ, 2004.

PACHECO, Ana Júlia; CUNHA JÚNIOR, Carlos Fernando Ferreira. Jogos Olímpicos de Atlanta, 1996: a imprensa e o "futebol de saias" do Brasil. Revista do Núcleo de Sociologia do Futebol/UERJ. Rio de Janeiro, n. 5, p. 95-108, 1997.

PEREIRA, Leonardo Affonso de Miranda. Footballmania: uma história social do futebol no Rio de Janeiro (1902-1938). Rio de Janeiro: Nova Fronteira, 2000.

SAHLINS, Marshall. O pessimismo sentimental e a experiência etnográfica: por que a cultura não é um objeto em via de extinção (parte I). Mana, Rio de Janeiro, v. 3, n. 1, p. 41-73, 1997.

SCOTT, Joan. Gênero: Uma categoria útil de análise. Educação e Realidade. Porto Alegre, v. 20, p. 71-99, 1995.

SOUSA, Eustáquia S. Meninos à marcha! Meninas à sombra! A história da educação física em Belo Horizonte (1897-1994). 1994. Tese (Doutorado em Educação)
- Universidade de Campinas, Campinas, SP, 1994. O ensino da educação física para turmas mistas: difícil demais. Dois Pontos, Belo Horizonte, n. 1, p. 78-82, 1997.

SOUSA, E.; ALTMANN. H. Meninos e meninas: expectativas corporais e implicaçóes na educação física escolar. Cadernos Cedes, ano XIX, n. 48, p. 52-68, 1999.

SPÓSITO, Marilia Pontes. Estudos sobre a juventude em educação. Revista Brasileira de Educação, ANPED, n. especial, p. 37-52, 1997.

VELHO, Otávio. De Bateson a Ingold: passos na constituição de um paradigma ecológico. Mana, Rio de Janeiro, v. 2, n. 7, p. 133-140, 2001.

Trabalhos de campo: antinomias e estradas de ferro. Aula inaugural no Instituto de Filosofia e Ciências Humanas da Universidade do Estado do Rio de Janeiro. Rio de Janeiro: UERJ, março, 2006.

WELZER-LANG, Daniel. A construção do masculino: dominação das mulheres e homofobia. Revista Estudos Feministas, Florianópolis, Tradução de Miriam Pillar Grossi, v. 9, n. 2, p. 460-485, 2001. autora Eliene Lopes Faria

Doutora em Educação/UFMG

Recebido em 24/03/2009

Aceito para publicação em 06/11/2009 